\title{
PROFITABILITAS USAHA PETERNAKAN AYAM PEDAGING "FK" DI DESA MATUNGKAS KECAMATAN DIMEMBE KABUPATEN MINAHASA UTARA
}

\author{
Sheyren Carmella Effendy \\ Nordy F.L. Waney \\ Yolanda P.I. Rori
}

\begin{abstract}
ABSRACT
This study aims to determine the profitability of broiler farming business owned by $F K$ for 1 year in Matungkas Village Dimembe Subdistrict of North Minahasa Regency based on Profit Margin Ratio on Sales, ROA, ROE. This research is Case Study study using Primary data and Secondary data. Primary data collection is done by direct interviews with business owners and employees including business results and costs. Secondary data is obtained from Matungkas Village Office, Dimembe District Office, Minimum BPS Office, Agriculture Department Kab. Minut. Data were analyzed by descriptive method. Profitability of broiler trading business in analysis by using Profit margin on sales analysis, Return On Asset (ROA), Return On Equity (ROE). The results showed Gross profit margin (GPM), Net profit margin (NPM), Return on assets, Return on equity period II and IV increased due to demand of chicken many in that period in August and December due to the need for religious holidays. Periods I, III and V decreased due to reduced production factor and there was no religious holiday period so high profit was in period II and IV.
\end{abstract}

Keywords: profitability, poultry husbandry farm "FK", Matungkas Village, Dimembe District

\begin{abstract}
ABSTRAK
Penelitian ini bertujuan untuk mengetahui profitabilitas usaha peternakan ayam pedaging milik FK selama 1 tahun di Desa Matungkas Kecamatan Dimembe Kabupaten Minahasa Utara berdasarkan rasio Profit Margin On Sales, ROA, ROE. Penelitian ini adalah penelitian Studi Kasus menggunakan data Primer dan data Sekunder. Pengambilan data primer dilakukan dengan cara wawancara langsung dengan pemilik usaha dan karyawannya meliputi hasil usaha dan biaya-biaya. Data sekunder yaitu diperoleh dari Kantor Desa Matungkas, Kantor Kecamatan Dimembe, Kantor BPS Minut, Dinas Pertanian kab. Minut. Data di analisis dengan metode deskriptif. Profitabilitas usaha peternakan ayam niaga pedaging di analisis dengan menggunakan analisis Profit margin on sales, Return On Asset (ROA), Return On Equity (ROE). Hasil penelitian menunjukan Gross profit margin (GPM), Net profit margin (NPM), Return on asset, Return on equity periode II dan IV mengalami kenaikan disebabkan permintaan ayam banyak di periode tersebut (bulan Agustus dan Desember) karena kebutuhan hari raya keagamaan. Periode I, III dan V mengalami penurunan disebabkan karena faktor produksi berkurang dan periode tersebut tidak ada hari raya keagamaan. Keuntungan yang tinggi ada pada periode II dan IV.
\end{abstract}

Kata kunci: profitabilitas, peternakan ayam pedaging "FK", Desa Matungkas, Kecamatan Dimembe 


\section{PENDAHULUAN}

\section{Latar Belakang}

Sektor pertanian merupakan sektor yang memegang peranan penting dalam pembangunan perekonomian di Indonesia. kondisi perekonomian di berbagai sektor pertanian telah memacu untuk meningkatkan pendapatan masyarakat baik di Pedesaan maupun di Kota. Ini dilihat dari kegiatan usaha pertanian khususnya di bidang peternakan. Peternakan merupakan salah satu dari lima subsektor pertanian. Peternakan adalah kegiatan memelihara hewan ternak untuk di budidayakan dan mendapatkan keuntungan dari kegiatan tersebut (Rasyaf dalam Nizam,2013). Subsektor peternakan terbagi menjadi ternak besar, yaitu sapi (perah/potong), kerbau, dan kuda, dan ternak kecil yang terdiri dari kambing, domba, dan babi serta ternak unggas (ayam, itik, dan burung puyuh). Kegiatan usaha yang banyak dilakukan dalam subsektor peternakan adalah usaha agribisnis ayam ras pedaging. Ayam pedaging disebut juga ayam broiler merupakan salah satu komoditi peternakan yang cukup menjanjikan karena produksinya yang cukup cepat untuk kebutuhan pasar dibandingkan dengan produk ternak lainnya.

Keunggulan ayam ras pedaging antara lain pertumbuhannya yang sangat cepat dengan bobot badan yang tinggi dalam waktu yang relatif pendek, konversi pakan kecil, siap dipotong pada usia muda serta menghasilkan kualitas daging berserat lunak (Nizam,2013). Konsumsi daging ayam broiler di dorong oleh Pemerintah untuk meningkatkan asupan gizi masyarakat mengingat kandungan gizi ayam broiler yang baik dan juga mudah di akses masyarakat karena harga yang relatif murah di bandingkan harga daging jenis lain. Jumlah konsumsi per kapita tersebut, individu memperoleh asupan gizi harian sebesar kalori 19,73, protein 1,19 dan lemak 1,63. Jumlah ini termasuk kecil di banding dengan konsumsi perkapita negara lain. Kecamatan Dimembe merupakan satu di antara wilayah yang mengembangkan peternakan ayam pedaging di kabupaten Minahasa Utara. Jumlah populasi ternak ayam ras pedaging yang ada di Kabupaten Minahasa Utara berdasarkan data dari Badan Pusat Statistik, Sulawesi Utara Tahun 2014 yaitu berjumlah 1.286 .400 ekor.
Tabel 1. Jumlah Populasi Ayam Ras Pedaging Di Kabupaten Minahasa Utara Tahun 2013-2014

\begin{tabular}{lcccc}
\hline & \multicolumn{3}{c}{ Jenis Unggas } & Type Of I \\
\cline { 2 - 5 } $\begin{array}{l}\text { Kecamatan/ } \\
\text { District }\end{array}$ & $\begin{array}{c}\text { Ayam } \\
\text { Petelur/ } \\
\text { Loying Hen }\end{array}$ & $\begin{array}{c}\text { Ayam Pedaging/ } \\
\text { Broiler }\end{array}$ & $\begin{array}{c}\text { Ayam Buras/ } \\
\text { Notive } \\
\text { Chicken }\end{array}$ & $\begin{array}{c}\text { Itik/ } \\
\text { Duck }\end{array}$ \\
\hline 1. Kema & 0 & 5.400 & 11.500 & 650 \\
2. Kauditan & 40.000 & 215.000 & 16.431 & 572 \\
3. Airmadid & 40.000 & 185.000 & 12.694 & 163 \\
$\quad$ i & & & & \\
4. Kalawat & 0 & 275.000 & 14.590 & 746 \\
5. Dimembe & 70.000 & 226.000 & 18.053 & 480 \\
6. Talawaan & 20.000 & 105.000 & 10.501 & 127 \\
7. Likupang & 0 & 60.000 & 4.483 & 606 \\
$\quad$ Selatan & & & & \\
8. Likupang & 0 & 0 & 9.245 & 106 \\
$\quad$ Timur & & & & \\
9. Likupang & 0 & 65.000 & 16.363 & 224 \\
$\quad$ Barat & & & & \\
10.Wori & 0 & 150.000 & 10.583 & 160 \\
2014 & 170.000 & 1.286 .400 & 124.504 & 3.834 \\
2013 & 170.000 & 771.900 & 123.795 & 3.770 \\
\hline Sumber : BPS Minaha Utara 2016
\end{tabular}

Tabel 1 menunjukan bahwa usaha dalam bidang peternakan ayam sangat besar kemungkinannya mengalami kerugian, tidak sedikit usaha peterakan yang mengalami kerugian dan pada akhirnya menutup usahanya. Tujuan utama dari setiap kegiatan usaha yaitu mendapatkan keuntungan yang besar termasuk di dalamnya usaha peternakan ayam pedaging milik FK di Desa Matungkas Kecamatan Dimembe Kabupaten Minahasa utara, jumlah ayam yang dimiliki adalah 5000 ekor. Peternakan ayam tersebut baru di mulai usahanya dan berdiri pada bulan Februari 2016 dibandingkan dengan usaha peternakan ayam yang ada di Desa Matungkas lainnya. Hal ini menunjukan bahwa adanya kemungkinan keuntungan yang besar di tinjau dari lamanya beternak dengan jumlah ayam yang besar. Peternakan ayam pedaging ini juga merupakan pola kemitraan. Satu diantara pengukur yang digunakan untuk mengetahui seberapa jauh usaha peternakan ayam untuk mencapai keberhasilan usaha dengan analisis profitabilitas yaitu rasio Profit Margin On Sales, Return On Asset (ROA), Return On Equity(ROE). Profitabilitas merupakan kemampuan perusahaan untuk menghasilkan laba yang dihasilkan dari penjualan dan pendapatan usaha ayam pedaging selama 1 tahun, semakin besar tingkat keuntungan menunjukkan semakin baik manajemen dalam mengelola perusahaan. Rasio profit Margin on sales yaitu gross profit margin merupakan presentase laba kotor di bandingkan dengan penjualan selama 1 tahun, semakin besar gross profit margin semakin baik keadaan perusahaan. Net profit margin mengukur laba bersih setelah 
pajak terhadap penjualan selama 1 tahun,semakin tinggi net profit margin semakin baik keadaan perusahaan. ROA merupakan kemampuan perusahaan dalam memanfaatkan total aktiva untuk memperoleh laba, semakin tinggi rasio ini maka semakin baik keadaan perusahaan. ROE kemampuan perusahaan untuk menghasilkan tingkat pengembalian perusahaan atau efektifitas perusahaan dalam menghasilkan laba dengan memanfaatkan modal, semakin tinggi rasio ini maka semakin baik keadaan perusahaan (Syamsudin,2004). Berdasarkan uraian diatas tersebut menimbulkan ketertarikan untuk meneliti tentang profitabilitas usaha peternakan ayam pedaging milik FK di Desa Matungkas Kecamatan Dimembe Kabupaten Minahasa Utara.

\section{Rumusan Masalah}

Berdasarkan latar belakang, yang menjadi rumusan masalah dalam penelitian ini yaitu bagaimana profitabilitas usaha peternakan ayam pedaging milik FK di Desa Matungkas Kecamatan Dimembe Kabupaten Minahasa Utara berdasarkan rasio Profit Margin On sales, ROA, ROE?

\section{Tujuan Penelitian}

Penelitian ini bertujuan untuk mengetahui profitabilitas usaha peternakan ayam pedaging milik FK selama 1 tahun di Desa Matungkas Kecamatan Dimembe Kabupaten Minahasa Utara berdasarkan rasio Profit Margin On Sales, ROA, ROE.

\section{Manfaat Penelitian}

Penelitian ini bermanfaat untuk memberikan informasi mengenai keadaan usaha peternakan ayam pedaging di daerah penelitian sehingga dapat mengambil langkah yang tepat untuk keberhasilan usaha peternakan ayam pedaging. Hasil penelitian ini diharapkan dapat menjadi refrensi bagi peneliti selanjutnya.

\section{METODE PENELITIAN}

\section{Waktu dan Tempat Penelitian}

Waktu penelitian dilakukan dari Bulan Februari sampai dengan Bulan Mei 2017. Penelitian ini dilakukan di Desa Matungkas Kecamatan Dimembe, Kabupaten Minahasa Utara.

\section{Jenis dan Sumber Data Penelitian}

Penelitian ini adalah penelitian Studi Kasus menggunakan data primer dan data sekunder. Pengambilan data primer dilakukan dengan cara wawancara langsung dengan pemilik usaha dan karyawannya meliputi hasil usaha dan biaya-biaya. Data sekunder yaitu diperoleh dari Kantor Desa Matungkas, Kantor Kecamatan Dimembe, Kantor BPS Minut, Dinas Pertanian Kabupaten Minahasa Utara.

\section{Definisi Operasional dan Pengukuran Variabel}

Adapun variabel yang diukur dalam penelitian ini adalah:

1. Profitabilitas adalah kemampuan perusahaan untuk menghasilkan laba berdasarkan pendapatan selama periode tertentu yang terdiri dari:

a. Gross profit Margin adalah kemampuan perusahaan dalam menghasilkan laba kotor dari ayam pedaging selama periode tertentu. Gross profit margin diukur berdasarkan tingkat perbandingan antara penjualan dengan harga pokok penjualan selama 1 tahun, yang dinyatakan dalam persen (\%)

b. Net Profit margin adalah kemampuan perusahaan dalam menghasilkan laba bersih dari ayam pedaging selama periode tertentu. Net profit margin di ukur berdasarkan perbandingan antara laba bersih dengan penjualan bersih selama 1 tahun, yang dinyatakan dalam persen $(\%)$

c. Return on asset adalah kemampuan perusahaan dalam memanfaatkan aktiva untuk menghasilkan laba selama periode tertentu. Return on asset diukur berdasarkan perbandingan antaralaba bersih setelah pajak dengan total aktiva selama 1 tahun, yang dinyatakan dalam persen $(\%)$

d. Return on equity adalah kemampuan perusahaan dalam memanfaatkan equity untuk menghasilkan laba selama periode tertentu. Return on equity diukur berdasarkan laba bersih setelah pajak dengan equity selama 1 tahun, yang dinyatakan dalam persen $(\%)$

2. Jumlah kepemilikan ternak adalah jumlah keseluruhan ayam pedaging yang dimiliki oleh peternak, yang dinyatakan dalam ekor.

3. Biaya pemeliharaan adalah biaya-biaya yang digunakan dalam proses pemeliharaan ayam 
yang terdiri biaya bibit (Rp)/ekor, biaya pakan (Rp)zak biaya obat-obatan (Rp)/botol, biaya vitamin dan biaya vaksin $(\mathrm{Rp}) / \mathrm{botol}$.

4. Biaya lainnya adalah biaya tambahan yang digunakan dalam proses pemeliharaan ayam yang terdiri atas listrik (Rp)/bulan, minyak(Rp)/liter, pompa air (Rp)/set, genset (Rp)/unit, gas (Rp)/tabung, tenaga kerja 2 orang (Rp)/bulan.

5. Penjualan adalah suatu usaha yang terpadu untuk mengembangkan rencana-rencana strategis yang diarahkan pada usaha pemuasan kebutuhan dan keinginan pembeli guna mendapatkan penjualan yang menghasilkan laba.

6. Laba kotor adalah penjualan bersih dikurangi harga pokok penjualan.

7. Pajak adalah kebijakan pemerintah yang berfungsi untuk membayar pengeluaran umum, berdasarkan undang-undang dan dapat dipaksakan.

8. Laba bersih setelah pajak adalah penghasilan bersih setelah dikurangi pajak.

9. Aktiva /asset adalah harta kekayaan yang dimiliki oleh pemilik usaha seperti tanah, bangunan (kandang).

10. Equity/modal adalah hak pemilik atas aktiva perusahaan yang merupakan kekayaan bersih, yaitu modal sendiri.

\section{Metode Analisis Data}

Data di analis dengan menggunakan metode deskriptif. Profitabilitas usaha peternakan ayam niaga pedaging dianalisis dengan menggunakan Analisis profitabilita yaitu Profit Margin On Sales, ROA, ROE

1. Profit Margin on sales

$$
\begin{aligned}
& \text { Gross Profit Margin }=\frac{\text { Gross profit }}{\text { Penjualan }} \times 100 \% \\
& \text { Net Profit Margin }=\frac{\text { Laba bersih setelah pajak }}{\text { Penjualan }} \times 100 \% \\
& \text { 2. } \quad \text { Return On Asset }(R O A) \\
& \text { Return on Asset }=\frac{\text { Laba bersih setelah pajak }}{\text { Total Aktiva }} \times 100 \% \\
& \text { 3. } \quad \text { Return on Equity }(R O E) \\
& \text { Return on equity }=\frac{\text { Laba bersih setelah pajak }}{\text { Equity }} \times 100 \%
\end{aligned}
$$

\section{HASIL DAN PEMBAHASAN}

\section{Deskripsi Objek Penelitian}

Usaha Peternakan Ayam Pedaging "FK" adalah peternakan ayam pedaging yang terletak di Desa Matungkas Kecamatan Dimembe Kabupaten Minahasa Utara. Usaha ayam pedaging mulai diusahakan bulan Februari tahun 2016. Jumlah ayam pedaging saat itu sebanyak 5000 ekor ayam pedaging. Usaha Peternakan ini memiliki tenaga kerja 2 orang dan merupakan pola kemitraan yang bekerja sama dengan perusahaan PT. Ciomas Adisatwa Manado. Ayam pedaging dari hasil usaha dijual langsung kepada perusahaan PT. Ciomas Adisatwa Manado dan juga di bawa untuk di jual di Pasar.

\section{Deskripsi Pola Kemitraan}

Pola kemitraan yang dilakukan oleh ayam pedaging dibentuk kemitraan dengan perusahaan ( inti ) pada lokasi tersebut. Pertama kali diperkenalkan oleh perusahaan PT. Ciomas Adisatwa Manado bekerja sama pada Tahun 2016. Pola yang berlaku dari bentuk kemitraaan dengan perusahaan mitra yaitu :

a. Penawaran dan membuat kesepakatan kontrak/perjanjian kerja sama secara tertulis oleh perusahaan kepada peternak.

b. Kesepakatan atas penentuan kerja oleh perusahaan yang berupa sapronak (Daily Old Chicken,DOC, pakan, obat-obatan, dan vaksin) selanjutnya kontrak harga jual ayam hidup dan berbagai bonus prestasi peternak.

\section{Persiapan Kandang}

Persiapan kandang merupakan awal merupakan proses dari pemeliharaan ayam. Persiapan kandang yang baik menentukan berhasil tidaknya dalam pemeliharaan, kesehatan ternak juga tergantung dari kenyamanan hidupnya dalam kandang. Persiapan kandang dimulai dari pembersihan atau pencucian dari kotoran ternak sebelummnya baik di lantai kandang dan kolong kandang. Kolong kandang ditaburi kapur untuk membunuh jamur, langkah selanjutnya adalah pemasangan tirai. Tujuan dari pemasangan tirai ini adalah untuk menjaga suhu dalam kandang serta menghindari cuaca buruk. Tirai dipasang sedemikian rupa untuk mempermudah membuka dan menutup apabila terjadi perubahan cuaca atau suhu dalam kandang. Suhu dalam kandang dapat terjaga sesuai dengan kebutuhan ayam. Persiapan selanjutnya pemasangan brooder (indukan) tempat pakan dan tempat air minum. Tempat pakan dan tempat air minum dipasang secara berselang-seling sedangkan, pemanas dipasang di tengah-tengah brooder. Persiapan terakhir adalah fumigasi kandang, bahan yang digunakan adalah desinfektan lalu disemprotkan ke seluruh bagian 
kandang agar supaya kandang tetap awet dan tidak mudah rapu. Semua persiapan kandang selesai maka DOC siap dimasukkan.

\section{Kandang Dan Peralatan Kandang}

Kenyamanan kandang sangat ditentukan oleh letak bangunan kandang. Persyaratan kandang di bangun jauh dari pemukiman, mudah dicapai sarana transportasi, mudah mendapatkan air bersih menggunakan sumur. Upaya yang dilakukan bagi kesehatan ternak sehingga terhindar penyebaran penyakit. Kandang yang digunakan terdiri dari 1 unit dengan menggunakan lantai dari sekat bambu tiang fandasi kandang terbuat dari beton . Ukuran 1 unit bangunan kandang adalah panjang 70m x 8m lebar dengan kapasitas 5000 ekor. Peralatan kandang yang digunakan sebagai berikut :

a. Tempat pakan. Tempat pakan yang digunakan terbuat dari plastik sehingga mudah dibersihkan. Umur 1-7 hari tempat pakan yang digunakan berbentuk bulat( baki) sebanyak 50 buah. Umur 10 sampai panen 200 buah .

b. Tempat air minum. Tempat air minum terbuat dari plastis. Dengan pengisihan air secara otomatis. Efektif dan menghemat tenaga setiap kotak dalam kandang menggunakan 108 buah tempat minum.

c. Pemanas. Sumber panas berasal dari mesin pemanas gas yang mengelurkan uap. Pada umur ayam 1- 7 hari pemanas dinyalakan 24 jam dengan suhu 3539c. Pemanas dihentikan setelah ayam berumur 12 hari dan disesuaikan dengan suhu dalam kandang. Lampu hanya digunakan sebagai penerangan malam hari dalam kandang, dengan kapasitas 5000 ekor menggunakan 36 buah balon lampu untuk 1-7 hari 42 watt 7 - panen 18 watt.

\section{Pemeliharaan}

\section{Bibit Ayam (Daily old chicken)}

Bibit merupakan faktor yang tidak bisa diabaikan, bibit ayam broiler yang berkualitas baik yaitu bibit dengan produksi daging yang tinggi degan konversi pakan yang sedikit. Jumlah bibit usaha peternakan ayam pedaging "FK" berjumlah 5000 ekor.

Tabel 2. Data Produksi Usaha peternakan Ayam Pedaging "FK" Tahun 2016-2017(periode I-V)

\begin{tabular}{|c|c|c|c|}
\hline Periode & Bulan & Jumlah Ayam (Ekor) & Harga $(\mathrm{Rp})$ \\
\hline $\mathrm{I}$ & Juni & 4900 & 18.000 \\
\hline II & Agustus & 4965 & 19.000 \\
\hline III & Oktober & 4980 & 18.000 \\
\hline IV & Desember & 5000 & 22.000 \\
\hline V & Februari & 4985 & 18.000 \\
\hline
\end{tabular}

Tabel 2 menunjukan bahwa jumlah ayam dari usaha peternakan ayam pedaging "FK" periode I sampai periode $\mathrm{V}$ berada pada kisaran 5000 ekor. Harga jual ayam tergantung dari perusahaan yang menjadi mitra juga mengalami fluktuasi.

\section{Pakan}

Usaha peternakan ayam pedaging "FK", pakan memegang peranan yang sangat penting dalam menjamin kelangsungan hidup usaha tersebut. Pakan mempengaruhi keberhasilan usaha peternakan ayam pedaging.

Tabel 3. Jenis pakan usaha peternakan ayam pedaging

\begin{tabular}{ccc} 
& \multicolumn{1}{c}{ "FK" } & Tahun 2016-2017 ( periode I-V) \\
\hline Jenis Pakan & Umur Ayam Broiler & Protein $(\%)$ \\
\hline SB 10 & 1-14 Hari & $22,5 \%$ \\
SB 11 & 14-21Hari & $21 \%$ \\
SB 12 & 21- Panen & $20 \%$ \\
\hline
\end{tabular}

Sumber : Data Primer 2016

Tabel 3 menunjukan bahwa jenis pakan usaha peternakan ayam pedaging ada 3 macam pakan ayam yaitu SB 10 mulai umur 1-14 hari, SB 11 umur 14-21 hari, SB 12 umur 21-panen. Bibit ayam atau daily old chicken datang, hal yang harus di lakukan pertama kali ayam dikeluarkan dari keranjang dan dihitung, menyalakan pemanas, kemudian pemberian air minum yang dicampur dengan air gula merah untuk mengembalikan kondisi ayam dan mengobati stress selama perjalanan. Ayam minum selama 45 jam kemudian diberikan air putih. Ayam diberikan pakan sedikit demi sedikit Pemberian pakan dilakukan 2 kali sehari yaitu pada pagi hari dan sore hari apabila air gula sudah habis diganti dengan air biasa. Ayam pedaging yang berumur 2 hari brooder yang ada diperluas di sesuaikan dengan pertumbuhan ayam. Komposisi pakan pada umur 1-14 hari protein 22,5 persen, komposisi pakan umur 14-21 hari protein 21 persen dan komposisi pakan umur 21-panen protein 20 persen .Kandungan gizi pakan SB10, SB11 lebih tinggi dibandingkan pada pakan SB12 mengingat pada umur tersebut merupakan masa pertumbuhan dan pembentukan jaringan tubuh tinggi untuk mencapai bobot badan yang maksimal pada saat dipasarkan. Pakan SB12 protein relatif lebih rendah karena ayam telah mencapai titik akhir pertumbuhan. Tempat pakan dan air minum digantung brooder dilepaskan dan diganti dengan sekat yang terbuat dari bambu saat 
ayam pedaging berumur 10 hari. Tirai dibuka setengah dan pada malam hari tirai kandang ditutup kembali. kandang dilepas seluruhnya saat ayam sudah berumur 16 hari. Pemberian pakan dilakukan 2 kali sehari yaitu pada pagi hari dan sore hari sedangkan air minum di berikan secara semuanya (Adlibitum).

\section{Obat-Obatan}

Obat-obatan yang digunakan usaha peternakan ayam pedaging "FK" terdiri dari obat, vitamin, vaksin dan desinfektan. Obat-obatan tersebut berfungsi untuk mencegah timbulnya penyakit, memacu pertumbuhan, menjaga kesehatan dan mengobati ternak ayam yang sakit selama periode pemeliharaan. Upaya pencegahan terhadap adanya serangan penyakit dilakukan sejak awal sebelum pemeliharaan, yaitu dengan desinfektan untuk kegiatan sterilisasi kandang dan peralatan sebelum digunakan. Kegiatan sterilisasi ini biasanya dilakukan 1-2 minggu sebelum DOC tiba, dengan tujuan untuk membunuh mikroorganisme penyebab penyakit yang masih tersisa dari periode pemeliharaan sebelummnya. Proses pemeliharaan kesahatan perlu mendapatkan perhatian. Upaya yang dilakukan adalah melalui pemberian vitamin, obat-obatan dan vaksinasi yang teratur. Pemberian vitamin dilakukan apabila terjadi perubahan cuaca untuk menghindari terjadinya stress pada ayam, sedangkan pemberian vaksin yang dicampurkan dengan air minum dan diberikan pada pagi hari. Panen dilakukan pada umur 28-36 hari dimana ayam sudah mencapai berat rata-rata $1,65 \mathrm{~kg} / \mathrm{ekor}$.

\section{Analisis Rasio Profitabilitas}

Analisis rasio profitabilitas merupakan bagian yang penting dan perlu dilakukan dalam suatu usaha untuk profitabilitas usaha peternakan ayam pedaging "FK". Analisis rasio profitabilitas merupakan cara untuk mengukur kemampuan usaha dalam menghasilkan keuntungan selama 1 tahun melalui penjualan, aktiva, dan modal. Analisis rasio profitabilitas dalam perhitungannya menggunakan rasio Gross Profit Margin (GPM), Net Profit Margin (NPM), Return on Asset (ROA), dan Return on Equity (ROE). Perhitungan Rasio Profitabilitas dalam angka dan presentase selama tahun 2016-2017 dalam Usaha Peternakan Ayam Pedaging di Desa Matungkas Kecamatan Dimembe Kabupaten Minahasa Utara. Gross Profit Margin ( GPM)Gross Profit Margin
(GPM) yaitu laba kotor dibandingkan dengan penjualan selama 1 tahun. Semakin besar gross profit margin maka semakin baik operasi perusahaan. Berikut tabel hasil perhitungan Gross Profit Margin (GPM) Usaha Peternakan Ayam pedaging "FK" selama 1 tahun (5 periode ). Hasil perhitungan selama 1 tahun dapat dilihat padaTabel 4.

Tabel 4. Marjin keuntungan kotor ( Gross Profit Margin) usaha peternakan ayam pedaging "FK" periode I-V Tahun 2016-2017

\begin{tabular}{llccc}
\hline Periode & Bulan & $\begin{array}{c}\text { Laba bersih sblm } \\
\text { pajak (Rp) }\end{array}$ & $\begin{array}{c}\text { Penjualan= } \\
(\mathrm{Rp})\end{array}$ & $\begin{array}{c}\text { GPM } \\
(\%)\end{array}$ \\
\hline I & Juni & 3.681 .000 & 88.200 .000 & 4,17 \\
II & Agustus & 64.155 .000 & 94.335 .000 & 68,0 \\
III & Oktober & 58.860 .000 & 89.640 .000 & 65,7 \\
IV & Desember & 78.112 .000 & 110.000 .000 & 71,0 \\
V & Februari & 59.350 .000 & 89.730 .000 & 66,1 \\
\hline \multicolumn{2}{l}{ Sumber : Data primer 2016 (diolah) }
\end{tabular}

Tabel 4 menunjukan periode I bulan juni laba bersih sebelum pajak 3.681 .000 dibandingkan dengan penjualan 88.200 .00 sehingga mendapatkan Hasil GPM 4,17 persen. Periode II bulan agustus Laba bersih sebelum pajak 64.155.000 dibandingkan dengan penjualan 94.335.000 sehingga mendapatkan hasil 68,0 persen. Periode III bulan oktober laba bersih sebelum pajak 58.860.000 dibandingkan dengan penjulan 89.640.000 sehingga mendapatkan hasil 65.7 persen. Periode IV bulan desember laba bersih sebelum pajak 78.112.000 dibandingkan dengan penjualan 110.000 .000 sehingga mendapatkan hasil 71,0 persen. Periode V bulan februari laba bersih sebelum pajak 59.350.000 dibandingkan dengan penjualan 89.730 .000 sehingga mendapatkan hasil 66,1 persen.

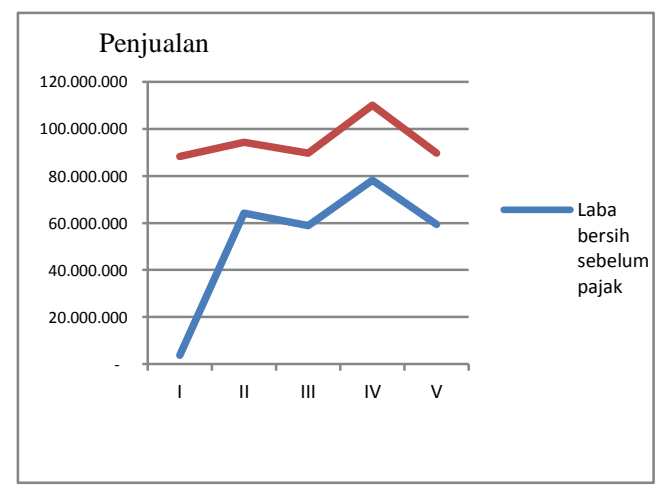

Gambar 1. Grafik trend laba bersih sebelum pajak dan penjualan selama 5 Periode Juni 2016Februari 2017. 
Gambar 1 menunjukan laba bersih sebelum pajak dengan penjualan selama 5 periode terjadi kenaikan. Penjualan lebih tinggi dari pada laba bersih setelah pajak tetapi keduanya cendrung mengalami kenaikan antara periode I ke II kemudian menurun antara periode II ke periode III dan meningkat antara periode III dan periode IV lalu menurun lagi antara periode IV ke V. Kenaikan terjadi disebabkan periode I ke periode II rendah kemudian naik karena masih memperhitungkan biaya investasi yang besar sementara di periode II sudah tidak di hitung biaya investasinya, terjadi penurunan karena faktor pasar harga Kemudian naik lagi pada periode III dan IV dibulan desember karena hari raya keagamaan (Natal, tahun baru) permintaan ayam daging banyak dan terjadi penurunanan periode $\mathrm{V}$ di bulan februari karena dibulan ini produksi kurang sudah lewat masa hari raya keagamaan ternyata GPM cendrung naik di bulan agustus dan bulan desember karena kedua periode mengalami keuntungan yang tertinggi.

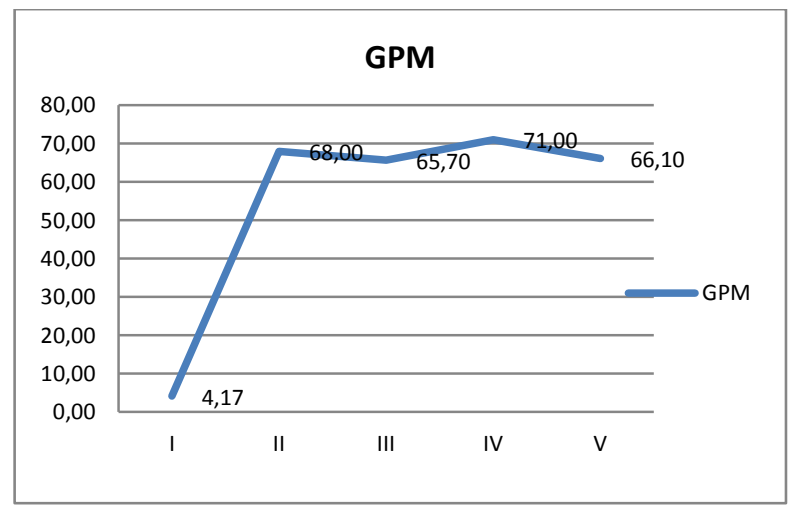

Gambar 2. Gross Profit Margin selama 5 Periode Juni 2016- Februari 2017

Gambar 2 menunjukan GPM cendrung mengikuti pola yang sama. GPM naik di bulan agustus dan desember karena kebutuhan hari raya keagaamaan pemintaan konsumen terhadap ayam daging banyak.

\section{Net Profit Margin}

Net Profit Margin (NPM) merupakan keuntungan penjualan setelah menghitung biaya dan pajak. Margin ini menunjukan kemampuan perusahaan dalam memperoleh laba bersih setelah pajak dibandingkan dengan penjualan selama 1 tahun. Semakin tinggi Net Profit Margin maka semakin baik operasi perusahaan. Berikut tabel hasil perhitungan Net Profit Margin (NPM)
Usaha Peternakan Ayam pedaging "FK" selama 1 tahun. Hasil perhitungan Net Profit Margin $(N P M)$ usaha peternakan ayam pedaging "FK" Selama 1 tahun (5 Periode) dapat dilihat pada Tabel 5.

Tabel 5. Marjin Keuntungan Bersih (Net Profit Margin) usaha peternakan ayam pedaging "FK" periode I-V Tahun 2016-2017

\begin{tabular}{llcrc}
\hline Periode & Bulan & $\begin{array}{c}\text { Laba bersih } \\
\text { setelah pajak (Rp) }\end{array}$ & $\begin{array}{c}\text { Penjualan } \\
(\mathrm{Rp})\end{array}$ & $\begin{array}{c}\text { NPM } \\
(\%)\end{array}$ \\
\hline I & Juni & 3.312 .900 & 88.200 .000 & 3,75 \\
II & Agustus & 57.739 .000 & 94.335 .000 & 61,2 \\
III & Oktober & 52.974 .000 & 89.640 .000 & 59,1 \\
IV & Desember & 70.300 .800 & 110.000 .000 & 63,9 \\
V & Februari & 53.415 .000 & 89.730 .000 & 59,5 \\
\hline \multicolumn{5}{l}{ Sumber: Data Primer $2016($ diolah) }
\end{tabular}

Tabel 5 periode, menunjukan periode I bulan juni laba bersih setelah pajak 3.312.900 dibandingkan dengan penjualan 88.200 .00 sehingga mendapatkan NPM 3,17 persen. Periode II bulan agustus Laba bersih setelah pajak 57.739.000 dibandingkan dengan penjualan 94.335.000 sehingga mendapatkan hasil 61,2 persen. Periode III bulan oktober laba bersih setelah pajak 52.974.000 dibandingkan dengan penjulan 89.640 .000 sehingga mendapatkan hasil 59,1 persen. Periode IV bulan desember laba bersih setelah pajak 70.300.800 dibandingkan dengan penjulan 110.000 .000 sehingga mendapatkan hasil 63,9 persen. Periode V bulan februari laba bersih setelah pajak 53.415.000 dibandingkan dengan penjualan 89.730 .000 sehingga mendapatkan hasil 59,5 persen.

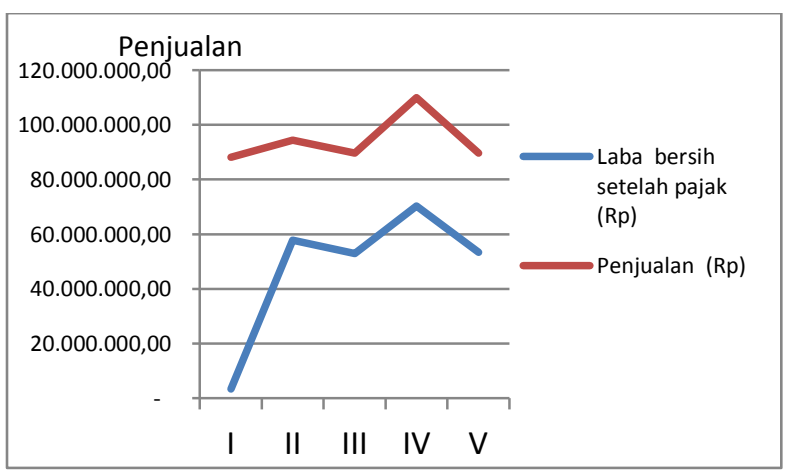

Gambar 3. Grafik trend laba bersih setelah pajak dengan penjualan selama 5 periode juni 2016februari 2017

Gambar 3 menunjukan laba bersih setelah pajak dengan penjualan selama 5 periode terjadi kenaikan. Penjualan lebih tinggi dari pada laba bersih setelah pajak tetapi keduanya 
cendrung mengalami kenaikan antara periode I ke II kemudian menurun antara periode II ke periode III dan meningkat antara periode II dan periode IV lalu menurun lagi antara periode IV ke V. Kenaikan terjadi disebabkan periode I ke periode II rendah kemudian naik karena masih memperhitungkan biaya investasi yang besar sementara di periode II sudah tidak di hitung biaya investasi dan volume penjualannya, terjadi penurunan karena faktor pasar permintaan berkurang. Kemudian naik lagi pada periode III dan IV dibulan desember karena hari raya keagamaan (Natal, tahun baru) permintaan ayam daging banyak dan terjadi penurunanan periode $\mathrm{V}$ di bulan februari karena dibulan ini produksi kurang sudah lewat masa hari raya keagamaan ternyata NPM cendrung naik di bulan agustus dan bulan desember karena kedua periode mengalami keuntungan yang tertinggi.

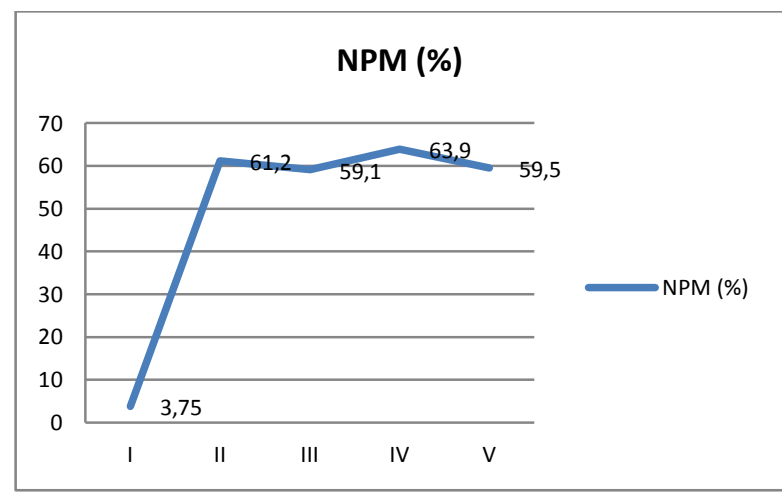

Gambar 4. Net Profit Margin selama 5 periode juni 2016-februari 2017

Gambar 4 menunjukan NPM cendrung mengikuti pola yang sama. NPM naik di bulan agustus dan desember karena kebutuhan konsumen sehingga permintaan banyak dihari raya keagaamaan meskipun harga ayam pedaging mahal.

\section{Return on Asset}

Return on asset ( ROA) merupakan pengukuran kemampuan perusahaan secara keseluruhan di dalam menghasilkan keuntungan dengan total aktiva yang tersedia di dalam perusahaan. Semakin tinggi rasio semakin baik keadaan perusahaan. Hasil perhitungan Return On Asset (ROA) usaha peternakan ayam pedaging "FK" Selama 1 tahun dapat dilihat pada Tabel 6.
Tabel 6. Keuntungan Pengembalian Asset (Return on Asset) usaha peternakan ayam pedaging "FK" periode IV Tahun 2016-2017

\begin{tabular}{llccc}
\hline Periode & Bulan & $\begin{array}{c}\text { Laba bersih setelah } \\
\text { pajak (Rp) }\end{array}$ & $\begin{array}{c}\text { Total } \\
\text { aktiva } \\
(\mathrm{Rp})\end{array}$ & $\begin{array}{c}\text { RO } \\
\mathrm{A} \\
(\%)\end{array}$ \\
\hline I & Juni & 3.312 .900 & 84.519 .000 & 3,92 \\
II & Agustus & 57.739 .500 & 84.519 .000 & 68,3 \\
III & Oktober & 52.974 .000 & 84.519 .000 & 62,6 \\
IV & Desember & 70.300 .800 & 84.519 .000 & 83,2 \\
V & Februari & 53.415 .000 & 84.519 .000 & 63,2 \\
\hline
\end{tabular}

Sumber: Data Primer 2016 (diolah)

Tabel 6, menunjukan periode I bulan Juni laba bersih setelah pajak Rp.3.312.900 dibandingkan dengan total aktiva Rp. 84.519 .000 sehingga mendapatkan pengembalian asset sebesar 3,92 persen. Periode II bulan Agustus laba bersih setelah pajak Rp.57.739.000 dibandingkan dengan total aktiva Rp. 84.519.000 sehingga mendapatkan pengembalian asset sebesar 68,3 persen. Periode III bulan Oktober laba bersih setelah pajak Rp.52.974.000 dibandingkan dengan total aktiva Rp. 84.519.000 sehingga mendapatkan pengembalian asset sebesar 62,6 persen. Periode IV bulan Desember laba bersih setelah pajak Rp.70.300.800 dibandingkan dengan total aktiva Rp.84.519.000 sehingga mendapatkan pengembalian asset sebesar 83,2 persen. Periode V bulan februari laba bersih setelah pajak Rp.53.415.000 dibandingkan dengan total aktivaRp. 84.519.000 sehingga mendapatkan pengembalian asset 63,2 persen.

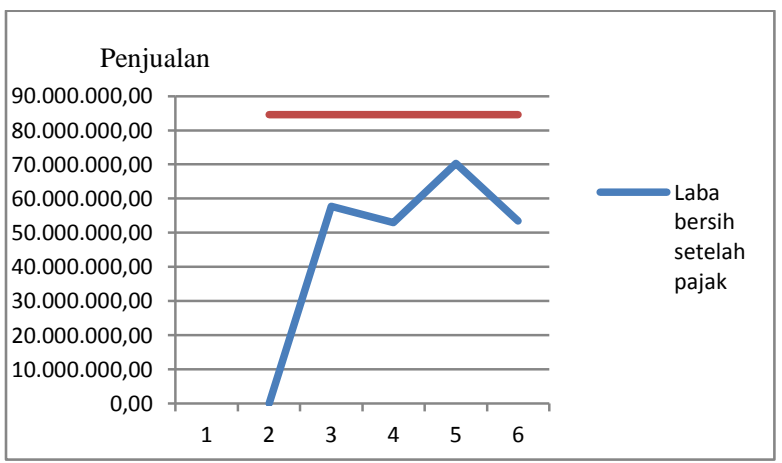

Gambar 5. Grafik trend laba bersih setelah pajak dan total aktiva selama 5 periode juni 2016februari 2017

Gambar 5 menunjukan laba bersih setelah pajak selama 5 periode terjadi kenaikan. Laba bersih setelah pajak cendrung mengalami kenaikan pada periode Periode I ke II kemudian menurun antara periode II ke periode III dan meningkat antara periode III dan periode IV lalu menurun lagi antara periode IV ke V. Kenaikan terjadi disebabkan periode I ke 
periode II rendah kemudian naik karena masih memperhitungkan biaya investasi yang besar sementara di periode II sudah tidak di hitung biaya investasi dan volume penjualannya, terjadi penurunan karena faktor pasar permintaan berkurang. Kemudian naik lagi pada periode III dan IV dibulan Desember karena hari raya keagamaan (Natal, tahun baru) permintaan ayam daging banyak dan terjadi penurunanan periode $\mathrm{V}$ di bulan februari karena dibulan ini produksi kurang sudah lewat masa hari raya keagamaan tetapi total aktiva lebih tinggi dari pada laba bersih setelah pajak karena jumlah asset periode I sampai V sama karena asset yang di perhitungkan adalah keseluruhan biaya investasi yang dikeluarkan. Jadi ROA cendrung naik di bulan agustus dan bulan desember karena kedua periode mengalami keuntungan yang tertinggi.

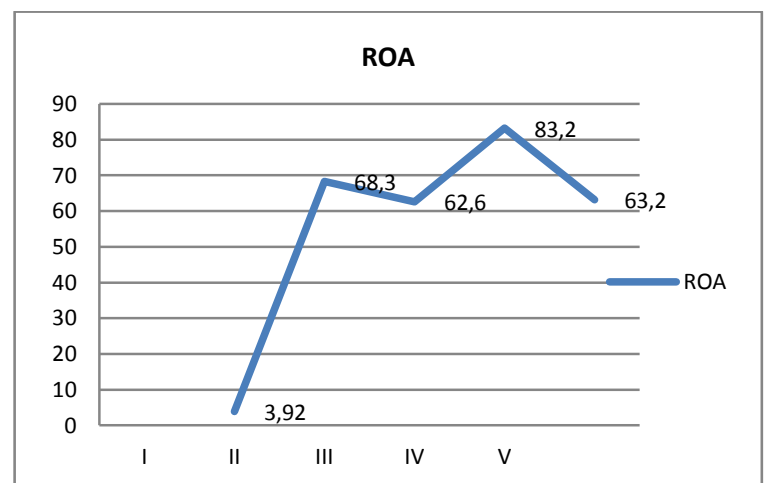

Gambar 6. Return On Asset selama 5 periode Juni 2016-Februari 2017

Gambar 6 menunjukan ROA cendrung mengikuti pola yang sama. ROA naik di bulan agustus dan desember karena kebutuhan konsumen sehingga permintaan banyak dihari raya keagaamaan meskipun harga ayam pedaging mahal.

\section{Return on Equity}

Return on Equity (ROE) adalah ukuran kemampuan perusahaan untuk menghasilkan tingkat kembalian perusahaan atau efektifitas perusahaan didalam menghasilkan keuntungan dengan memanfaatkan ekuitas (modal) yang dimiliki perusahaan. Semakin tinggi rasio ini semakin baik keadaan perusahaan. Hasil perhitungan Return on equity (ROA) usaha peternakan ayam pedaging "FK" Selama 1 tahun (5 Periode) dapat dilihat pada Tabel 7.

Tabel 7 periode, menunjukan periode I bulan juni laba bersih setelah pajak 3.312.900 dibandingkan dengan equity Rp.84.519.000 sehingga mendapatkan ROE 3,92 persen. Periode II bulan agustus Laba bersih setelah pajak Rp.57.739.000 dibandingkan dengan equity Rp.30.180.000 sehingga mendapatkan hasil 19,1 persen. Periode III bulan oktober laba bersih setelah pajak Rp.52.974.000 dibandingkan dengan equity Rp.30.780.000 sehingga mendapatkan hasil 17,2 persen. Periode IV bulan desember laba bersih setelah pajak Rp.70.300.800 dibandingkan dengan equity Rp.31.888.000 sehingga mendapatkan hasil 22,0 persen. Periode V bulan februari laba bersih setelah pajak Rp. 53.415.000 dibandingkan dengan equity Rp.30.380.000 sehingga mendapatkan hasil 17,5 persen.

Tabel.7 Keuntungan Pengembalian Modal ( Return On Equity) usaha peternakan ayam pedaging periode I-V tahun 2016-2017

\begin{tabular}{llccc}
\hline Periode & Bulan & $\begin{array}{c}\text { Laba bersih } \\
\text { setelah pajak (Rp) }\end{array}$ & $\begin{array}{c}\text { Equity } \\
(\mathrm{Rp})\end{array}$ & $\begin{array}{c}\text { ROE } \\
(\%)\end{array}$ \\
\hline I & Juni & 3.312 .900 & 84.519 .000 & 3,92 \\
II & Agustus & 57.739 .500 & 30.180 .000 & 19,1 \\
III & Oktober & 52.974 .000 & 30.780 .000 & 17,2 \\
IV & Desember & 70.300 .800 & 31.888 .000 & 22,0 \\
V & Februari & 53.415 .000 & 30.380 .000 & 17,5 \\
\hline Sumber: & Data Primer $2016($ diolah) & &
\end{tabular}

Sumber: Data Primer 2016(diolah)

Gambar 7, menunjukan laba bersih setelah pajak selama 5 periode terjadi kenaikan. Laba bersih setelah pajak cendrung mengalami kenaikan pada periode Periode I ke II kemudian menurun antara periode II ke periode III dan meningkat antara periode III dan periode IV lalu menurun lagi antara periode IV ke V. Kenaikan terjadi disebabkan periode I ke periode II rendah kemudian naik karena masih memperhitungkan biaya investasi yang besar, sementara di periode II sudah tidak di hitung biaya investasi dan volume penjualannya, terjadi penurunan karena faktor pasar permintaan berkurang. Kemudian naik lagi pada periode III dan IV dibulan desember karena hari raya keagamaan (Natal, tahun baru) permintaan ayam daging banyak dan terjadi penurunanan periode $\mathrm{V}$ di bulan februari karena dibulan ini produksi kurang sudah lewat masa hari raya keagamaan tetapi equity cendrung naik pada periode I lebih tinggi dari pada laba bersih setelah pajak karena modal yang dikeluarkan lebih besar dihitung biaya pembuatan kandang. Periode II sampai $\mathrm{V}$ mengalami penurunan ini disebabkan periode tersebut hanya dihitung modal yang dikeluarkan seperti biaya bibit, biaya pakan, biaya obat-obatan dan vaksin. Jadi ROE cendrung naik di bulan Agustus dan bulan desember karena kedua periode mengalami keuntungan yang tertinggi. 


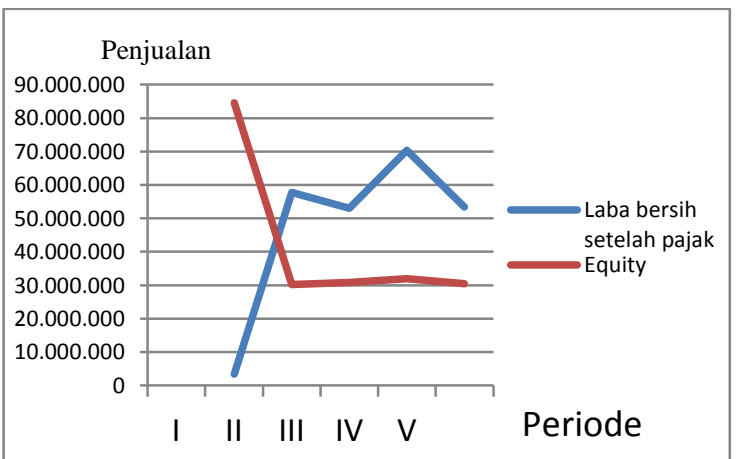

Gambar 7. Grafik trend laba bersih setelah pajak dan equity selama 5 periode juni 2016-februari 2017

Gambar 8 menunjukan ROE cendrung mengikuti pola yang sama. ROE naik di bulan agustus dan desember karena kebutuhan konsumen sehingga permintaan banyak dihari raya keagaamaan meskipun harga ayam pedaging mahal. Hasil perhitungan Rasio Profitabilitas akan terlihat lebih jelas pada Tabel 8 .

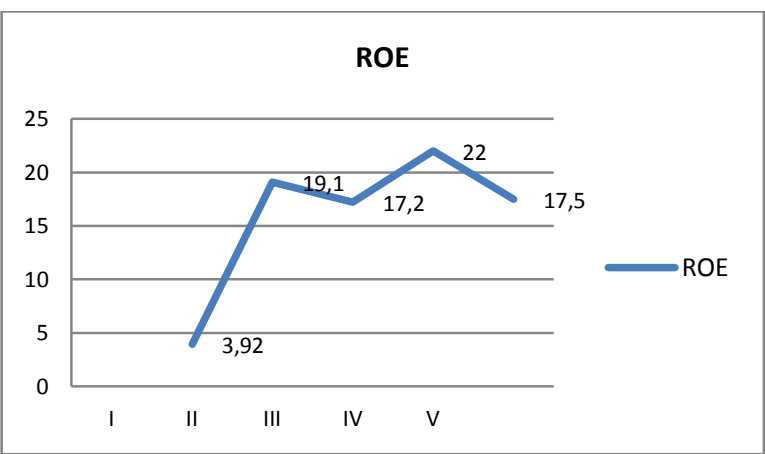

Gambar 8. Return On Equity selama 5 periode juni 2016-februari 2017

Tabel 8 dapat dilihat bahwa keseluruhan profitabilitas dari GPM, NPM, ROA, ROE. Periode IV terdapat nilai tertinggi yaitu GPM sebesar 71,0 persen, NPM sebesar 63,9 persen, ROA sebesar 83,17 persen, ROE sebesar 22,0 persen.

Tabel 8. Hasil perhitungan rasio profitabilitas usaha peternakan ayam pedaging periode I-V Tahun 20162017

\begin{tabular}{cccccc}
\hline \multicolumn{7}{c}{2017} & \multicolumn{3}{c}{ Periode } \\
\cline { 2 - 5 } Profitabilitas & I & II & III & IV & V \\
\hline GPM(\%) & 4,17 & 68,0 & 65,7 & 71,0 & 66,1 \\
NPM(\%) & 3,75 & 61,2 & 59,1 & 63,9 & 59,5 \\
ROE(\%) & 3,92 & 19,1 & 17,2 & 22,0 & 17,5 \\
ROA(\%) & 3,92 & 68,3 & 62,7 & 83,2 & 63,2 \\
\hline
\end{tabular}

Sumber: Data Primer 2016(diolah)

\section{KESIMPULAN DAN SARAN}

\section{Kesimpulan}

Kesimpulan penelitian ini adalah rasio profitabilitas gross profit margin dari periode II dan IV mengalami peningkatan disebabkan permintaan banyak. Periode I, III dan periode V gross profit margin mengalami penurunan yang disebabkan oleh naiknya penjualan. Net profit margin dari periode II dan IV mengalami peningkatan, hal ini berarti bertambahnya nilai laba bersih yang disebabkan oleh penjualan ayam yang semakin meningkat dikarenakan permintaan konsumen yang banyak. Laba bersih dari usaha ayam pedaging menguntungkan dari periode II dan IV. Periode I, III dan $\mathrm{V}$ laba bersih mengalami penurunan disebabkan karena produksi kurang, pemintaan terhadap ayam sedikit sehingga membuat penjualan menurun. Return On Asset (ROA) dari periode II dan IV mengalami peningkatan karena bertambahnya nilai laba bersih. ROA dalam pengembalian asset terhadap usaha ayam pedaging ini mengalami keuntungan. Periode I, III dan V mengalami penurunan hal ini disebabkan oleh naiknya total aktiva. Return on Equity (ROE) dari periode II dan IV mengalami peningkatan karena bertambahnya nilai laba bersih. Sehingga dalam pemanfaatan modal menguntungkan. Periode I, III dan V mengalami penurunan disebabkan oleh naiknya modal.

\section{Saran}

Menghasilkan keuntungan yang lebih baik lagi sebaiknya pihak perusahaan meningkatkan produksi dan pemilik usaha mempertahankan kualitas ayam pedaging dan juga mempertahankan mitra usaha yang baik untuk mencapai keuntungan maksimum tidak berfluktuasi.

\section{DAFTAR PUSTAKA}

BPS, 2015. Kabupaten Minahasa Utara. Badan Pusat Statistik. Sulawesi Utara Cholila Ita, 2014. Jurnal. Analisis Profitabilitas Terhadap Pengambilan Aset Usaha Ayam Petelur.

Pallutturi S, 2005. Ekonomi Kesehatan. Penerbit : Bagian administrasi dan kebijakan kesehatan FKM UNHAS.

Prihadi T, 2008. Analisis Rasio Keuangan. Cetakan 1. Penerbit PPM. Jl.Menteng Raya No. 9-19, Jakarta.

Salvatore, 2005. Managerial Economics: Ekonomi Manajerial Dalam Perekonomian Global. Jakarta.

Soemarso, S., 2004. Akuntansi Suatu Pengantar. Buku 2 edisi . Jakarta

Soekartawi, 2002. Prinsip Dasar Manajemen Pemasaran Hasil-Hasil Pertanian Edisi Revisi. Raja Grafindo Persada, Jakarta

Sugiarto dkk, 2005. Ekonomi Makro. Jakarta : Penerbit PT Gramedia Pustaka Utama.

Syamsudin, L., 2004. Manajemen Keuangan Perusahaan.Radja Grafindo Perkasa Jakarta. Edisi baru.

Wiasta, J.W 2010. Skripsi. Analisis Pengaruh Profitabilitas Terhadap Harga Saham Pada Lembaga Keuangan Yang Go Public di BEI Tahun 20042007

Widjajanta, B., (2007). Mengasah Kemampuan Ekonomi. Citra Praya; Bandung. 